\title{
Note on Dates, Transliteration and Other Editorial Practices
}

In I 700, Peter the Great adopted the Julian calendar, which was eleven days behind the Gregorian calendar in the eighteenth century, twelve days behind in the nineteenth and thirteen days behind in the twentieth. Thus the Bol'shevik Revolution took place in Russia on 25 October I9I 7 according to the Julian calendar but on 7 November according to the Gregorian calendar. The Gregorian calendar, which Western states had begun to adopt in preference to the Julian calendar in ${ }_{5} 582$, was not adopted in Russia until I918. In this book, dates are given in the Old Style (OS; i.e. according to the Julian calendar) when the event to which reference is made took place in pre-revolutionary Russia and in the New Style (NS; i.e. according to the Gregorian calendar) when it took place outside Russia. In some instances, the NS date is given in brackets after the OS date, e.g. I8 (29) August I77I.

\section{TRANSLITERATION}

We have followed the Library of Congress system of transliteration in the text, lists of references and endnotes in each chapter of this volume. Thus Russian surnames ending in -ский have been rendered with -skii (e.g. Dostoevskii) rather than the commonly used English form -sky (Dostoevsky). The Russian soft sign has everywhere been transliterated with an apostrophe, e.g. Gogol'. Russian words printed in pre-revolutionary orthography (e.g. the titles of eighteenth- and nineteenth-century journals) have been transliterated from their modernised form (thus Sovremennik rather than Sovremennik"). 


\section{FORMS OF FORENAMES}

We have preferred transliterated Russian forenames (e.g. Aleksandr, Ekaterina, Petr) to translated ones (Alexander, Catherine, Peter), except in the case of monarchs and other members of the Russian royal family (e.g. Alexander I, Catherine II, Peter the Great), who are familiar to the English-speaking reader from the translated form of their names. We also use the form Alexander in the case of the nineteenth-century thinker Herzen, because we refer to him by the German form of his surname which will be familiar to English speakers.

\section{QUOTATIONS IN FOREIGN LANGUAGES}

Quotations and individual words that are given in the text in the language of the original are italicised (and, if they are in Russian, with modernised Cyrillic orthography). Where there is a need to indicate that certain parts of an italicised quotation were highlighted in some way in the original source, we have done this by use of bold font.

\section{TRANSLATION OF QUOTATIONS IN FOREIGN LANGUAGES}

In many cases (for example, when authors are merely quoting an opinion or a statement about a fact), we have not considered it necessary to retain the language of the original and the quotation has been translated into English. However, in many other cases (for instance, when language usage is being illustrated), it has seemed important to retain the original. In these cases, we have also provided a translation. Our policy has been to put the translation in an endnote, in order not to break the flow of the text of the chapter, unless the quotation is very short (five words or fewer).

In chapters translated from French or Russian by Derek Offord (these are indictated in the preface) he is also responsible for the translation of quotations from those languages. In the remaining chapters, which were written by their authors in English, the translation belongs to the author(s) of the chapter in question, unless otherwise indicated. 


\section{TRANSLATION OF TITLES}

In the text of each chapter, titles of novels, plays, poems, articles, chapters and other works written in a language other than English have been translated, but the original title (in transliterated form, if it was in Russian) is usually also given, in brackets, when the work is mentioned in the chapter for the first time. In the references, as a rule, only the foreign-language title is given.

\section{TITLES OF PERIODICALS}

Titles of Russian periodicals, on the other hand, are presented in the text of a chapter in their transliterated form. A translation of the title is also given, in brackets, when the title is first mentioned in that chapter. Likewise, titles of French periodicals are left in their original form, but are also translated at first mention in the text.

\section{ORTHOGRAPHY IN QUOTATIONS}

In quotations in English and French we have retained the spelling, accents and use of capitals of the original. In quotations from Russian documents of the pre-revolutionary era, however, we have modernised the orthography, eliminating, for example, the hard sign at the end of words ending in a hard consonant and replacing obsolete letters with those that have been used instead since the Russian orthographic reform of 1918 .

\section{DATES OF WORKS}

Dates given in parentheses after the titles of works mentioned in the text are, unless otherwise stated, the date of first publication, not the date of composition.

\section{REFERENCES IN THE TEXT}

In general, references to sources are given in the text, in accordance with the author-date system, but if the reference is very lengthy (as in the case of some references to archival sources) then it may be placed in an endnote instead. 


\section{ELLIPSES}

Where we have omitted material from a quotation or title we have indicated the omission by use of three dots in square brackets (i.e. [. . .]), in order to distinguish this type of ellipsis from suspension points (i.e. . .) that have been used by the author who is being quoted. 